IZA DP No. 5434

Turning 18: What a Difference Application of Adult Criminal Law Makes

Horst Entorf

January 2011 


\title{
Turning 18: What a Difference Application of Adult Criminal Law Makes
}

\author{
Horst Entorf \\ Goethe University Frankfurt \\ and IZA
}

\section{Discussion Paper No. 5434 \\ January 2011}

\author{
IZA \\ P.O. Box 7240 \\ 53072 Bonn \\ Germany \\ Phone: +49-228-3894-0 \\ Fax: +49-228-3894-180 \\ E-mail: iza@iza.org
}

Any opinions expressed here are those of the author(s) and not those of IZA. Research published in this series may include views on policy, but the institute itself takes no institutional policy positions.

The Institute for the Study of Labor (IZA) in Bonn is a local and virtual international research center and a place of communication between science, politics and business. IZA is an independent nonprofit organization supported by Deutsche Post Foundation. The center is associated with the University of Bonn and offers a stimulating research environment through its international network, workshops and conferences, data service, project support, research visits and doctoral program. IZA engages in (i) original and internationally competitive research in all fields of labor economics, (ii) development of policy concepts, and (iii) dissemination of research results and concepts to the interested public.

IZA Discussion Papers often represent preliminary work and are circulated to encourage discussion. Citation of such a paper should account for its provisional character. A revised version may be available directly from the author. 


\section{ABSTRACT \\ Turning 18: \\ What a Difference Application of Adult Criminal Law Makes ${ }^{*}$}

This paper contributes to the literature on specific deterrence by addressing the issue of selecting adolescents into adult and juvenile law systems. In Germany, different from the U.S. and most other countries, turning a critical cutoff age does not cause a sharp discontinuity from juvenile to adult penal law, but rather implies a shift to a discretionary system of both adult and juvenile law, dependent on the courts' impression of moral and mental personal development of the adolescent at the time of the act. The German legal system draws the line of adulthood at some fuzzy age interval between 18 and 21, which is well above the thresholds prevailing in the U.S. (16 to 18 years, state specific) and other countries such that the German evidence entails some external evidence to the previous literature mostly relying on U.S. data. Based on a unique inmate survey and two-equation models controlling for selectivity problems, results show that application of adult criminal law instead of juvenile penal law decreases expected recidivism of adolescents.

JEL Classification: $\quad \mathrm{K} 14, \mathrm{C} 52, \mathrm{~K} 42, \mathrm{H} 11$

Keywords: crime, recidivism, treatment effects, selection, survey data

Corresponding author:

Horst Entorf

Goethe University Frankfurt

Department of Economics

Grüneburgplatz 1

D-60323 Frankfurt

Germany

E-mail: entorf@wiwi.uni-frankfurt.de

\footnotetext{
* The author is most grateful to Stefan Pichler and Daniel Römer for their inspiring cooperation and suggestions during some earlier stage of the project as well as to Birgit Herrmann for her insightful proofreading of the paper.
} 


\section{Introduction}

There is an ongoing debate on the appropriate way of punishing adolescent offenders. In the U.S., in response to increasing violence of minors during the 1990s, nearly all states moved to ease the process of transferring serious juvenile offenders to the adult criminal justice system (Myers 2003, Bishop 2000). The criminal policy of other nations is more reluctant in applying the harsher adult criminal law to young criminals. Based on the literature on personal development, opponents of the "get tough" movement argue that it seems to be more beneficial to put them back on the "right track" by using educational and disciplinary measures, as youths are generally more inclined towards criminal activity (e. g. Heinz 2004, Thornberry, Huizinga, and Loeber 2004), which can be explained by a contemporary maturity gap (Moffitt 1993). This leads to the belief that juveniles are more rehabilitable and less culpable than adults (Mears, Hay, Gertz, and Mancini 2007). However, recent developments showing an increasing number of highly aggressive and serious acts of violence committed by minors question the ruling criminal policy (see Aebi 2004, Oberwittler and Hoefer 2005). In Germany, the ongoing media coverage of violent crimes resulted in a strong pressure on politics (Bundestag 2009) to touch upon the question on how to deal with juvenile and adolescent offenders.

A major drawback of the existing empirical studies is the strong limitation to U.S. data, because U.S. courts treat individuals as adults already at an early age. 47 states use 17 or 18 as the age at which most minors are treated as adults (Rosch et al. 2007). North Carolina, Connecticut and New York draw the line of adulthood for criminal culpability even at the age of 16. Hence, most research on specific deterrence is based on transferring 16- and 17-yearolds to adult criminal courts such that the validity on the deterrence hypothesis is limited to younger age groups. The German criminal law system provides some interesting alternative institutional framework (see Dünkel, 2005, for historical, institutional and both adult and juvenile law details). Unlike the U.S. system and other European countries, all individuals below 18 are strictly treated under juvenile penal law. Turning 18 does not automatically lead to the application of adult criminal law. Young adults, considered and defined as 'adolescents' ('Heranwachsende') in terms of the law (18 to under 21 years of age), might be treated the same as juveniles (14 to 18 years old). Whether adolescents were acting '[...] equal to a juvenile regarding moral and mental development at the time of the act' in the sense of $\S 105$ of the German Juvenile Justice Act ('Jugendgerichtsgesetz', JGG) or not depends on the 
discretionary margin of prosecutors and judges. ${ }^{2}$ Similar regulations exist in some other European countries such as Austria, Croatia, Greece, Italy, the Netherlands and Spain (Dünkel 2005). ${ }^{3}$

This paper contributes to the literature on specific deterrence by addressing the issue of selecting adolescents into adult and juvenile law systems. In particular, we focus on prison inmates belonging to the discretionary 'adolescent' group (18 to under 21 years of age) and compare expected recidivism of those convicted under adult criminal law to recidivism of those treated as juveniles. This setting provides new evidence because the design is different from the U.S. paradigm prevailing in the literature. Results are also of related interest for public policy, in particular in Europe, as the German model is used as a fighting crime strategy in other countries.

The data is based on a unique survey on 31 German prisons (German Inmate Survey, see Entorf et al., 2008, Entorf 2009). The econometric approach applies recursive two-equation models (bivariate probit, treatment regressions) which distinguish between a selection equation (selecting individuals to either the adult or the juvenile law) and a treatment equation. The latter captures the causal effect of interest, i.e. the impact of adult treatment on expected recidivism.

Contrary to the bulk of results based on U.S. data found in the criminological literature, results indicate that application of harsher adult criminal laws decreases the expected recidivism of adolescents.

This paper is organized as follows. Chapter 2 gives a short review of related literature. In Chapter 3, a description of the data is provided. Methods and identification strategy are presented in Chapter 4. Chapter 5 informs about econometric results. Chapter 6 gives a short summary and concludes.

\footnotetext{
${ }^{2}$ Note that all cases of young adults $(<21)$ are transferred to the jurisdiction of juvenile courts who decide on application of adult or juvenile law.

${ }^{3}$ In most European countries, the age of full criminal responsibility is below 21. For instance, application of adult law at the age of 18 is mandatory in Denmark, England/Wales, Finland, France, Sweden and Norway (Dünkel 2005).
} 


\section{Previous Research}

Research addresses the role of "specific deterrence" and "general deterrence" on future criminal behavior. Rational choice models (Becker 1968) of general deterrence predict that increasing severity and certainty of expected punishments should lead to a decline in crime. Hence, the threat of harsher "adult punishments" will give adolescents pause before they continue committing crimes. Put differently, adolescents have little incentive to curb criminal behavior if they can expect to be treated under the more lenient juvenile law. Evidence in favor of the general deterrence theory was given by Levitt (1998), who showed that the greater the difference between the stricter adult system and the lenient juvenile system, the more the crime rate declined when an increasing number of juveniles were transferred to adult criminal courts. In a more recent paper, Lee and McCrary (2009) found evidence that young adults did hardly respond to the harsher adult law when turning 18, a result that contradicts Levitt's (1998) findings who showed that there is less crime when adolescents pass into the adult system. In line with the majority of criminologists (see Redding 2003, and Fagan2008, for surveys), Lee and McCrary (2009) argue that those young offenders can be characterized as myopic, who are unfazed by the threat of short prison sentences and discount the consequences and likelihood of longer imprisonments.

Research on specific deterrence concerns the pros and cons of applying harsher punishment on adolescent offenders in order to reduce the likelihood of future reoffending. Fagan (2008) summarizes the recent criminological literature which is mostly based on U.S. data. The studies typically compare court outcomes and recidivism rates for matched groups of transferred and retained youths. According to his survey, research on transfer of juveniles to adult criminal courts suggests that recidivism rates are either the same or significantly higher for transferred youths than for youths retained in the juvenile court. Some studies comparethe criminal records of similar groups of youths either for the same time period or for different time periods before and after law changes. However, as pointed out by Fagan (2008), most of the studies introduce selection biases that prevent a true comparison of individuals with and without the 'adult' treatment. A major problem is that many studies do not control for preexisting indices for criminal propensity that may then affect the outcomes. Hence, differences in the recidivism rates of both samples may reflect more about such pre-existing propensities than about the differential treatment effects. However, some few studies address these selection issues. Winner et al. (1997) matched cases in the juvenile and adult courts on seven 
criteria. $^{4}$ Lanza-Kaduce, Lane, Bishop, and Frazier (2005) used propensity scores (Rosenbaum and Rubin 1984) to adjust for selection effects in the transfer process. The differences in recidivism rates using this strategy show substantially higher recidivism rates for transferred youth. Applying the same method, their result is confirmed by Fagan et al. (2004) who compared recidivism rates among samples of youths recruited from New York City whose cases originated in the criminal court, with samples from bordering areas in northeastern New Jersey whose cases were processed in the juvenile court. Further studies by Myers (2003), Podkopacz and Feld (1995), and Thornberry, Huizinga and Loeber (2004) come to the same conclusion.

Hjalmarsson (2009) used a different approach for testing the specific deterrence hypothesis. Contrary to the bulk of research, she is testing the deterrence effect of juvenile facilities when the alternative would be sentencing without incarceration (i.e. probation or fine). Applying a regression discontinuity design that is based on sentencing either to custody or to more lenient measures depending on binding guidelines ("sentencing grid”) for Washington state juvenile courts, she identifies the causal effect by comparing the recidivism rate of individuals who are close to the critical sentencing grid on either side of the cutoff, i.e. juveniles without incarceration on the one side of the grid and juveniles with incarceration on the other side of the grid. Her study shows that incarceration in juvenile facilities can be an effective measure of combating juvenile crime.

A major drawback of the existing empirical studies is the limitation to U.S. data such that most research on specific deterrence is based on transferring 16- and 17-year-olds to adult criminal courts. As outlined in the Introduction, depending on the severity of the crime and the maturity of the defendant, adolescent delinquents can be sentenced according to either juvenile or criminal law. There is no special court for juveniles. Inspecting recidivism rates for those who are convicted either under juvenile law or under criminal law in Germany and released when they were between 18 and 24 years old, it turns out that recidivism rates are higher for those who are treated as juveniles. ${ }^{5}$ Of course, apart from age this comparison

\footnotetext{
${ }^{4}$ However, besides information on prior offenses, data on the individual background is rather limited: only age at the time of committing the offense, gender and race are considered.

5 Jehle, Heinz and Sutterer (2003) analysed official register data on recidivism within a four years period (1994 to 1998). The recidivism rate after being released from an unconditional prison sentence under juvenile law was 79.0\% for 18-to-20-year-olds and 74.9\% for 21-to-24-year-olds (Jehle et al. 2003, p. 109). Respective recidivism rates after unconditional prison sentences under adult criminal law were $46.2 \%$ (18 to 20 years of age) and 49.9\% (21 to 24 ) (Jehle et al. 2003, p. 107). Aggregating over all age groups, the recidivism rate within four years after unconditional prison sentence under juvenile law was $77.8 \%$, whereas it was $54.9 \%$ for adults.
} 
might still be biased by selection due to other factors such as education, family background or labor market prospects (Entorf 2009).

\section{Data and Descriptive Evidence}

This analysis is based on a prison survey of 1,771 German inmates. The survey (German Inmate Survey, Entorf et al., 2008) uses a two-stage approach that combines stratified and random sampling. First, a representative sample of the population of prisons in Germany was created. Second, a random draw out of this population completed the sampling.

The survey data was collected in 31 German prisons in 2003 and 2004 using a questionnaire with 123 questions. In order to account for the different nationalities of the inmates, the questionnaire was distributed in either German, Turkish, Serbo-Croatian, Russian, Polish or English language. The survey was organized and performed by a team of researchers from Darmstadt University of Technology. It was first analyzed by Entorf (2009). ${ }^{6}$

The convicts of the dataset can be grouped into three subsamples: inmates in pretrial custody, inmates sentenced under juvenile law and inmates sentenced under criminal law. Since this study focuses on the effect of the applied law type, only the last two subgroups are used and inmates in pretrial custody are dropped. Furthermore, as the main research interest is on juveniles and young adults, only individuals aged between 15 and 22 when they committed the crime are considered relevant for the analysis. This results in a subsample of 159 inmates. The descriptive statistics can be found in Table 1.

The crucial variable of interest is expected recidivism. It is constructed from the response to the following survey question:

(1) Could it occur that after your release from custody you come into conflict with the law and end up in prison?

Tick your assessment on the following 5-point scale, whereby a 1 stands for "no, never", and a 5 stands for “absolutely certain":

$\begin{array}{clllc}\text { No, never } & & & \begin{array}{c}\text { Absolutely certain } \\ \text { I'll be in again }\end{array} \\ \mathrm{O} & \mathrm{O} & \mathrm{O} & \mathrm{O} & \mathrm{O} \\ 1 & 2 & 3 & 4 & 5\end{array}$

\footnotetext{
${ }^{6}$ Interviews with judicial employees suggest an overrepresentation of the more active group of inmates. However, when comparing the sample characteristics to those of the average prison population in Germany, there no evidence of a selection bias was found (see Entorf et al. 2008).
} 
Answers to this question are transformed into a binary variable expected recidivism. Given the ordered categories of the survey question, ordered discrete choice models would have been the natural alternative to the performed binary response model. The reason for summarizing categories is the rather small number of 159 observations in the age-at-offense group of interest. Summarizing categories prevents misinterpretations of subjective survey questions and avoids problems arising from sparsely filling in certain survey categories, in particular due to the often found rare use of extreme survey categories.

Table 1: Descriptive Statistics, Conditional on age at offence $\in(15,22]$

\begin{tabular}{lccccc}
\hline Variable & Nobs & Mean & Std. Dev. & Min & Max \\
\hline recidivism (expectation) & 159 & .2893082 & .4548739 & 0 & 1 \\
age at offense & 159 & 18.9908 & 1.870697 & 15.25 & 22 \\
age & 159 & 21.18868 & 2.679434 & 16 & 29 \\
male & 159 & .9308176 & .2545658 & 0 & 1 \\
married & 159 & .081761 & .274866 & 0 & 1 \\
poor social capital & 159 & .4842767 & .5013317 & 0 & 1 \\
no church & 159 & .3396226 & .4750775 & 0 & 1 \\
criminal family background & 159 & .2201258 & .4156404 & 0 & 1 \\
Abitur & 159 & .0503145 & .2192837 & 0 & 1 \\
addiction (alcohol or drugs) & 159 & .2893082 & .4548739 & 0 & 1 \\
job contact & 159 & .1949686 & .3974282 & 0 & 1 \\
schooling & 159 & 9.836478 & 2.102212 & 2 & 17 \\
length (of prison sentence) & 157 & 3.167994 & 2.641088 & .167 & 15 \\
(application of) criminal law & 159 & .3018868 & .4605269 & 0 & 1 \\
murder & 159 & .1194969 & .3253971 & 0 & 1 \\
sexual offence & 159 & .0503145 & .2192837 & 0 & 1 \\
assault & 159 & .3144654 & .4657696 & 0 & 1 \\
robbery & 159 & .3117647 & .4645827 & 0 & 1 \\
theft & 159 & .4150943 & .4942951 & 0 & 1 \\
fraud & 159 & .1823899 & .3873857 & 0 & 1 \\
illicit drugs: consumption & 159 & .0754717 & .2649855 & 0 & 1 \\
illicit drugs: dealing & 159 & .1383648 & .3463734 & 0 & 1 \\
vandalism & 159 & .1194969 & .3253971 & 0 & 1 \\
\hline Not d & & & & 0 & 0 \\
\end{tabular}

Note: descriptive statistics under the restriction that variables show valid observations on 'recidivism'; Data Source: German Inmate Survey (Entorf et al. 2008).

In the data, the answers are positively skewed: $43.5 \%$ of the respondents answered with the lower extreme "No, never" while only $4 \%$ said they were absolutely certain to reoffend. Therefore, we set expected recidivism to zero if the respondent chose either answer 1 or 2 , and set the binary variable to one for those with a higher self-reported probability of ending up in prison again (answers 3-5).

One might raise objections against using perceived expected recidivism as a proxy for real recidivism and actual criminal behavior. However, there are at least three arguments in favor 
of self-assessments. First, there is evidence that expected and real recidivism are correlated (see for instance Corrado 2003, Lochner 2007). Second, using expected recidivism in contrast to actual recidivismavoids the problem of a selection bias which arises when conducting follow-up surveys collecting information on realized recidivism. Third, when studying joint distributions of expected recidivism and related covariates researchers do not have to rely solely on unconditional recidivism rates (without any meaningful background information such as socioeconomic or family situations) as they can be found in most recidivism surveys (as in Jehle et al. 2003, for German recidivism rates).

The crucial variable for the assigned type of law is the age at the time when the crime was committed ('age at offense'). Since this information did not appear directly in the survey, it is constructed by using time and age when inmates were interviewed and the time when the crime was committed. With regard to the latter, inmates could choose to indicate either a point in time or an interval. In the case of a point in time, the calculation is straightforward. When dealing with an interval, it is not very clear which point in time to take. For these cases, we took the upper bound of the interval, since German juvenile law (Jugendgerichtsgesetz, JGG) allows judges to apply adult criminal law once the delinquent has reached the critical age when committing his criminal acts (§ $32 \mathrm{JGG).}$

Table 2 informs about expected recidivism of juveniles (age at offense $<18$ ) dependent on age (at the time of the interview). Young offenders who committed their crimes when they were younger than 18 seem to be very pessimistic when still young (below 18): Here, expected recidivism is 0.5 which is clearly above the average rate of 0.29 . Older cohorts originating with the same age at offense show less pessimistic assessments of their future, and after a couple of years (age $\geq 21$ ) they even seem to respond in a rather optimistic way (0.14), although this evidence cannot be generalized because it is based on only 7 observations.

Table 2: Expected Recidivism of Juveniles (age at offense $<18$ )

\begin{tabular}{c|c|c}
\hline \multicolumn{3}{c}{ Age (at time of survey) } \\
$<18$ & {$[18,21)$} & $\geq 21$ \\
\hline $0.50(8)$ & $0.29(41)$ & $0.14(7)$ \\
\hline
\end{tabular}

Notes: Share of inmates with "expected recidivism $=1$ " whose age at the time of the offense was below 18; number of respondents in parentheses. Data: German Inmate Survey (Entorf et al., 2008). 
The age group $[18,21)$ is of particular importance because for criminals of this age German judges decide about application of either criminal or juvenile law (JGG). Table 3 considers expected recidivism of the age-of-offense group [18,21), and it distinguishes between those who are convicted under juvenile law and those who are sentenced under adult conditions. Preliminary descriptive evidence suggests that those convicted under juvenile law expect markedly higher rates of recidivism, conditional on the age at the time of the interview. Ignoring age, the average recidivism rate of 'juveniles' would only be slightly higher than that of 'adults' (0.34 compared to 0.31$)$.

Table 3: Expected Recidivism of Adolescent Offenders

\begin{tabular}{ccc}
\hline & \multicolumn{2}{c}{$\begin{array}{c}\text { Age at time of offense (related to present prison sentence) }= \\
{[18,21)}\end{array}$} \\
\hline $\begin{array}{c}\text { Age (at time of } \\
\text { interview) }\end{array}$ & $\begin{array}{c}\text { Application of juvenile penal } \\
\text { law }\end{array}$ & $\begin{array}{c}\text { Application of (adult) criminal } \\
\text { law }\end{array}$ \\
\hline$[18,21)$ & $0.35(20)$ & $0.00(1)$ \\
{$[21,23)$} & $0.29(31)$ & $0.25(8)$ \\
$\geq 23$ & $0.60(5)$ & $0.35(17)$ \\
\hline Average (all age groups) & $0.34(56)$ & $0.31(26)$ \\
\hline
\end{tabular}

Notes: Share of inmates with "expected recidivism $=1$ " whose age at the time of the offense was at least 18 but under 21 years of age; number of respondents in parentheses. Data: German Inmate Survey (Entorf et al. 2008).

Of course, age and maturity of young criminals are important factors of recidivism, but many other covariates are of similar relevance. One of these variables is gender (male). Consistent with national criminal survey statistics, there is a strong majority (90\%) of male inmates in our sample. We also control for marital status (married). In our sample, only $8.2 \%$ are married, which is probably due to the fact that we are looking at inmates aged 15 to 22 when committing the crime. Further, we measure participation in social clubs, e. g. sports clubs or the voluntary fire brigade, mapping the lack of active participation into the dummy variable poor social capital. Almost half of the inmates in question (48.4\%) reported no active participation in social clubs. Furthermore, religious affiliation might play an important role in terms of beliefs and intrinsic motivation. The corresponding dummy variable no church is set to one for all inmates that do not belong to any religion which holds true for $33.9 \%$ in our sample.

Crime and education are often found to be negatively correlated. This study includes education measured as the number of years spent in school (schooling). As education is a positive asset in the legal labor market, it should reduce the probability to reoffend. However, 
education might also be of importance to judges who have to decide to what extend suspects are fully responsible for their behavior or whether individual maturity is lagging behind. Poor or high educational levels of adolescents might help judges in making her or his decision about which penal law to choose. Abitur measures the educational degree which is usually achieved after 18 or 19 years of age; it qualifies for university entrance in Germany. For the relevant subgroup of inmates with age at offense between 18 and 21 years the ratio is 5.3\%. (full sample: 5.0\%, see Table 1).

Recidivism heavily depends on future legal perspectives. Labor market opportunities play a leading role. The analysis includes the binary variable job contact which is set to one for all inmates reporting to have a job opportunity when leaving jail which is the case for $19.5 \%$ of the relevant inmates. ${ }^{7}$ Recidivism is likewise linked to alcohol and drug addiction, both in a direct way - in the sense that addicted people might more easily commit crimes under the influence of drugs - and in an indirect way in the sense that these people might see criminal behavior as a way to finance their habits (see for instance Entorf \& Winker 2008, Goldstein 1985 or Harrison 1992). In the sample, 30.2\% of the inmates suffer from at least one of these addictions. Furthermore, criminal family background could matter for expected recidivism. This dummy variable captures past convictions of parents or siblings and applies for $22 \%$ of the inmates in the sample.

Finally, the survey contains detailed information on the crime committed and the corresponding sanction. Many delinquents have a criminal record of different offences resulting in multiple crime types being reported by a single individual. The most frequently reported crime is theft (41.5\%), followed by assault (31.4\%) and robbery (31.2\%).

In terms of applied legislation, 30.2\% of all delinquents in the sample were sanctioned under adult criminal law. For the important subsample of those who committed their crime between 18 and 21 years of age, this share is $28.2 \%$ (Table A3, Appendix). We also observe the length of a prison sentence measured in years. In line with German legislation, lifelong punishments (recorded as 'lifelong' in the data) are recoded as a 15 year sentence, which is also the maximum custody length found in the sample.

As mentioned above, depending on age at offense different laws might apply. Delinquents can thus be grouped into three groups. Juveniles can only be sentenced according to juvenile law (Table A2, 55 observations), adolescents can be penalized by either juvenile or criminal law

\footnotetext{
${ }^{7}$ See Entorf (2009) for a discussion of the influences of school and job market opportunities on criminal behavior and recidivism.
} 
(Table A3, 78 observations) and adults who have to be sentenced under criminal law (Table A4, 26 observations). Thus, to sharpen the contrast between juvenile law and adult law, the sample of the fuzzy age-at-offence group $[18,21)$ is enhanced by criminals of similar age either strictly subject to adult or strictly subject to juvenile law. Subsequent econometric results will be based on both samples, i.e. age at offence $\in(15,22]$ and $\in[18,21)$.

A comparison of the three groups reveals some significant differences at the descriptive level. ${ }^{8}$ There are only male juveniles and more than $93.6 \%$ male adolescents while we have 23.1\% female adult offenders in our sample, representing a statistically significant drop. As expected, there is a statistically significant rise in the share of married respondents when moving from juvenile to adolescent offenders. Furthermore, the years of schooling increase in age yielding a significant difference between juveniles and adolescents.

In addition, there are further notable but non-significant differences between groups. The rate of recidivism seems to be similar in the first two groups (approx. 30\%) but lower for the group of adults (18\%). Also, job contacts decrease with age which seems to indicate that inmates have a harder time to reenter the legal job market when getting older. We find sentence length to increase with age, which seems natural because adult persons get more severe sentences. In terms of crime types we see that almost all crimes become less frequent as the age increases. Especially interesting is vandalism, which does not show up at all for adult $(>21)$ delinquents. The only crimes that are increasing with age are fraud, sexual offences, drug dealing and drug consumption. However, as for all differences described in this paragraph, the change between the groups is not significant.

\section{Legal Background and Econometric Identification Strategy}

The main goal of this study is to focus on young adults ('adolescents') who were at least 18 years of age when they committed their offences and to compare the expected recidivism of those who are sentenced under adult criminal law ('Strafgesetzbuch', StGB) to the one of adolescents sentenced under juvenile penal law ('Jugendgerichtsgesetz', JGG). According to German legislation, juvenile law is mandatory for all delinquents aged less than 18 when committing the crime. For offenders of at least 18 but less than 21 years of age at offense, the legislator (§ 105 JGG, Jugendgerichtsgesetz) left the decision to the (juvenile) courts whether

\footnotetext{
${ }^{8}$ In terms of the difference of two sample means we consider them as statistically significantly different from each other using a two sample t test if the significance of their difference is higher than $10 \%$.
} 
to apply juvenile or criminal law. Finally, delinquents of at least 21 years have to be sentenced under general criminal law. With regard to the treatment assignment function, German legislation specifies that criminal law should be applied whenever the adolescent offender does not appear to be similar to a juvenile, neither in terms of personal development nor in the type of crime committed. Using these maturity criteria, judges of adolescents of the age-at-offense group $[18,21)$ have to evaluate which law to apply. It is quite obvious that the judge's decision will hinge on observables (like age) but also on unobservables (like maturity) which, however, likewise determine expected recidivism. Thus, when evaluating the recidivism rate of both penal law regimes, there is a potential endogeneity problem and the treatment effect cannot be estimated by simply inspecting sign and magnitude of treatment dummy variables.

Figure 1: Estimated Probability of Applying Adult Criminal Law

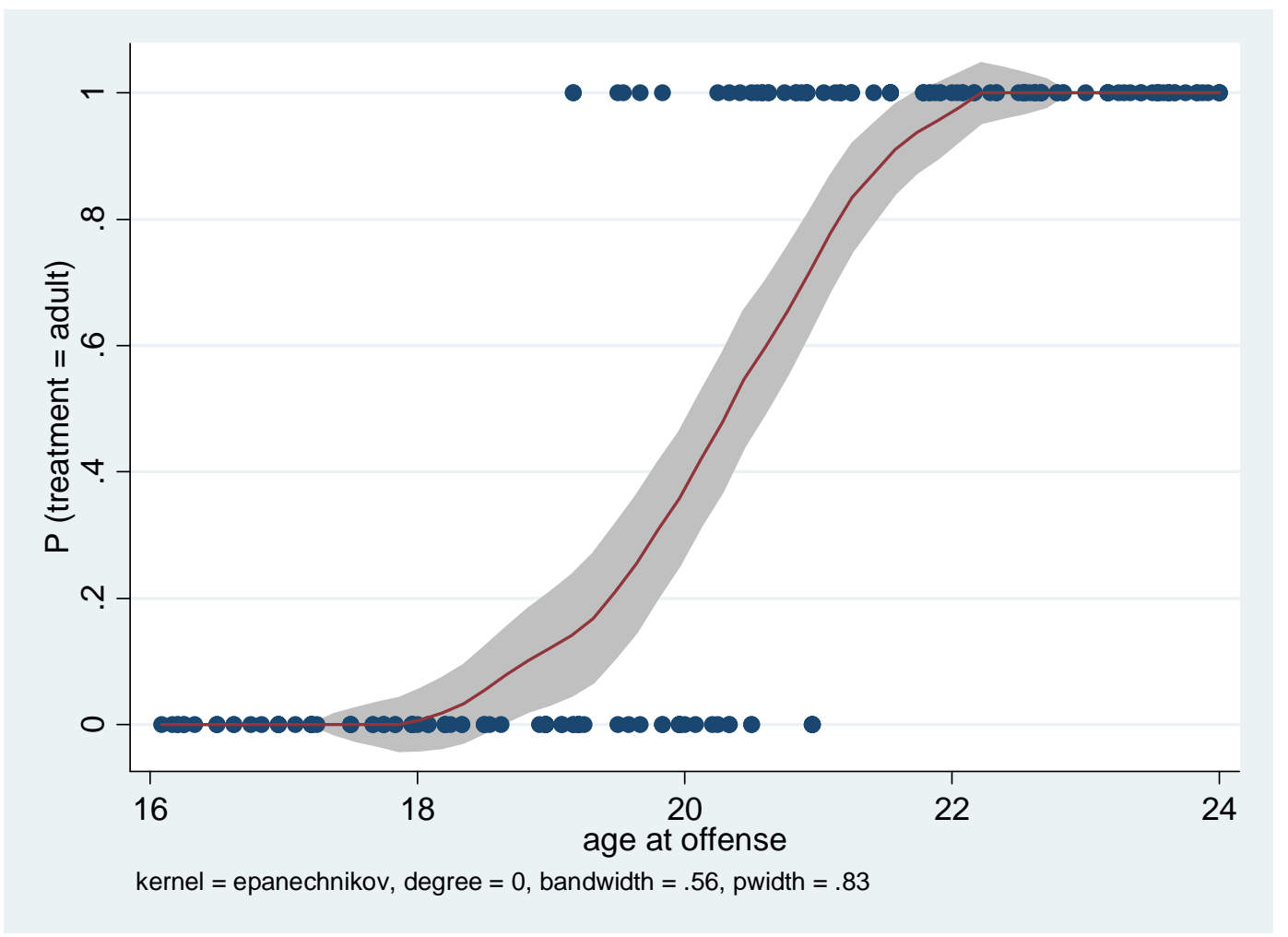

Note: Local Polynomial Regression, incl. 95\% confidence interval; Data: See Table 1.

The first idea was to tackle the endogeneity problem by using the regression discontinuity design (see Imbens and Lemieux 2008, and Van der Klaauw 2008, for surveys), and by inspecting recidivism rates just before and after turning 18 . However, the propensity score is almost zero until 'age at offense' equals 19 years of age at the time of committing the offense, 
as can be seen from Figure $1 .^{9}$ Thus, RD does not work smoothly, neither in a sharp nor a fuzzy framework, when the legislative cut-off point 'age at offense=18' is not effective, even not at some closer neighbourhood. Entorf et al. (2010) experimented with different alternative cut-off points at age at offense > 18 which, however, clearly bears the major problem of considerable arbitrariness.

In order to transfer the legal restrictions into a statistical model, the framework has to deal with the problem that turning 18 entails a change from definite application of juvenile penal law (applied to all minors under 18 years of age) to a different 'fuzzy' law status. The fact that juveniles turn 18 might already entail some deterrent effect on its own, irrespective of being treated as juvenile or adult. At the same time, turning 18 implies a second (nested) and potentially more severe shift from juvenile law to adult criminal law, given the person is convicted accordingly. Thus, the equation of interest on expected recidivism should provide information on the effect of both cutoffs, i.e. 'being at least 18 years of age or older at the time of committing the offence' and 'being at least 18 years of age at the time of committing the offence and being convicted under criminal law'. An equation that accounts for both effects on expected recidivism of inmate $i$ (in prison $j$ ) is

$$
E R_{i}=z_{i} \beta+\rho_{1} D_{i}+\rho_{2} T_{i}+\varepsilon_{i},
$$

where $D_{i}=1$ if the person was at least 18 years old at the time of the offence ( 0 otherwise), and where the treatment $T_{i} \equiv D_{i} A_{i}=1$ indicates application of the adult criminal law with $A_{i}=1$ representing adult criminal law, $A_{i}=0$ juvenile penal law.

Equation (1) includes a vector of explanatory factors $z_{i}$ and a residual $\varepsilon_{i}$. The latter might include some prison specific influences which are taken into account by correcting for unobserved clustering effects. Obviously, the interpretation of the treatment effect $\rho_{2}$ would be limited when we estimated eq. (1) by ordinary least squares because of the selection problem outlined before: Young inmates who committed their crimes when they were above the critical age of 18 (but still younger than 21) are committed under 'adult' conditions for good reasons, which might include some more serious criminal backgrounds, advanced criminal careers and a higher risk of recidivism (when convicted as juvenile). Thus, treatment as an

\footnotetext{
${ }^{9}$ Actually, for those inmates who are treated under adult conditions the youngest age at the time of committing the offence found in the survey is 19. The local polynomial regression (using optimized bandwidths) provides smooth transitions from zero to non-zero probabilities.
} 
adult, $T_{i}$, should be considered as endogenous, depending on correlated and common factors which motivate courts treating young adults under (adult) criminal law:

$$
T_{i}^{*}=x_{i} \gamma+e_{i}, \quad \text { where } T_{i}=\left\{\begin{array}{ll}
1 & \text { if } T_{i}^{*}>0 \\
0 & \text { otherwise }
\end{array} \text { and } \operatorname{cor}\left(\varepsilon_{i}, e_{i} \mid z, x\right)=r\right. \text {. }
$$

Under the hypothesis that being treated as adult or not depends on both observable and unobservable factors covering the propensity for continuing the criminal behavior, it is assumed that unobserved factors which cause judges to rule under adult law lead to higher recidivism of convicted offenders: Thus, $\operatorname{cor}\left(\varepsilon_{i}, e_{i}\right)=r$ is expected to be positive.

The econometric problem is that both recidivism in eq. (1) and the potentially endogenous 'adult' treatment in eq. (2) are binary variables. A straightforward approach would be to estimate eq. (1) by applying a two-stage probit procedure (à la 2SLS), i.e. first run a probit of $T$ on all exogenous variables and get the fitted probability $\hat{\Phi}$, then run probit on $z, D$ and $\hat{\Phi}$. However, as pointed out in the literature (see Imbens and Wooldridge (2009, lecture 6, Angrist and Pischke 2009, Chapter 4) estimating these so called “forbidden regressions” does not work because it would require passing the expected value through a nonlinear function. As there are no known two-step methods that allow one to estimate probit models with discrete endogenous variables, Imbens and Wooldridge (2009, lecture 6, p. 28) advocate the use of bivariate probit models with binary endogenous explanatory variables. Accordingly, a bivariate probit model in the tradition of Maddala (1983, p.123) will be estimated (it is called a 'recursive, bivariate probit model’ by Greene and Henscher 2010, p. 90):

$$
\begin{aligned}
& P(T=1 \mid x)=\Phi(x \gamma) \\
& P(E R=1, T=1 \mid z, D, T, x)=\Phi_{2}\left(z \beta+\rho_{1} D+\rho_{2} T, x \gamma, r\right) .
\end{aligned}
$$

Note that the endogenous nature of $T$ on the right-hand side variable of the second equation can be ignored in nonlinear maximum likelihood estimations (see, e.g., Greene 2008, p 823, Imbens and Wooldridge, lecture 6, p. 28). Another advantage of the bivariate probit model compared to the linear case is that there is no exclusion restriction required for identification: exogenous variables may appear in both equations (Greene and Hensher, 2010, p. 91). The only restriction is that there needs to be at least one exclusion restriction in the bivariate probit first stage (Angrist and Pischke 2009, p. 199).

Primary interest is in the consistent estimation of the parameter $\rho_{2}$ (and not in estimating endogenous probabilities of recidivism) such that treatment-effects models can be considered 
as alternative estimation strategy. They test the effect of an endogenously chosen binary treatment on another endogenous continuous variable, conditional on two sets of independent variables. Thus, unlike in bivariate probit models, endogenous expected recidivism will be estimated within a linear probability model. ${ }^{10}$ Details are outlined in Maddala (1983, 117122) and Greene (2008, p. 889-890). The model makes use of Heckman's (1979) correction approach (for endogeneity, not selection) such that the expected rate of recidivism for those treated under adult criminal law can be estimated using the inverse Mills ratio:

$$
\begin{aligned}
E\left(E R_{i} \mid T_{i}=1, x_{i}, z_{i}\right) & =z_{i} \beta+\rho_{1}+\rho_{2}+E\left(\varepsilon_{i} \mid e_{i}>-x_{i} \gamma\right) \\
& =\mathrm{z}_{i} \beta+\rho_{1}+\rho_{2}+r \sigma_{\varepsilon} \frac{\phi\left(x_{i} \gamma\right)}{\Phi\left(x_{i} \gamma\right)} .
\end{aligned} .
$$

The respective rate for those treated under juvenile law is

$$
\begin{aligned}
E\left(E R_{i} \mid T_{i}=0, x_{i}, z_{i}\right) & =z_{i} \beta+\rho_{1}+E\left(\varepsilon_{i} \mid e_{i}<-x_{i} \gamma\right) \\
& =z_{i} \beta+\rho_{1}+r \sigma_{\varepsilon}\left[\frac{-\phi\left(x_{i} \gamma\right)}{1-\Phi\left(x_{i} \gamma\right)}\right] .
\end{aligned}
$$

Identification of the causal treatment effect of interest, $\rho_{2}$, requires that exogenous factors of selectivity are included in $x_{i}$ and to have variables in $z_{i}$ that are not included in $x_{i}$. This exclusion restriction will be satisfied in the subsequent analysis. As already discussed in the previous section, courts consider age as a major factor influencing their decision. Moreover, types of crime and indicators of maturity will be used as explanatory variables in the selectivity equation. Individual labor market opportunities, social capital as well as alcohol and illicit drug problems serve as main factors $z_{i}$ of recidivism in the equation of interest.

\section{Results}

Table 4 presents results for the bivariate probit and treatment-effects models outlined above. Both frameworks combine the equation of interest (estimating the causal effect of the adult criminal law treatment) with a second equation which maps decisions of courts. They select adolescents/young adults either to the adult or the juvenile regime. All results are based on maximum-likelihood estimations (or, as argued in Huber 1967, and White 1982, on quasi-

\footnotetext{
${ }^{10}$ Angrist (2001) promote just using linear probability models estimated by 2SLS. The Heckman-two step model can be interpreted as a related control function approach. For conditions leading to equivalence of 2SLS and control functions see Imbens and Wooldridge (2009, lecture 6).
} 
maximum-likelihood if the distributional assumptions are not fully correct). The calculation of standard errors considers potential effects arising from stratification and clustering (in prisons). The sample is restricted to young prison inmates, because the focus of the study is on the distinction between juvenile law applied to defendants younger than 18 years of age and a case-based discretionary law applied to adolescents between 18 and 21 years of age. Empirical evidence relies on two nested age groups. The first one includes inmates of neighbouring age groups whose age at the time of the offense was between 15 and 22, the second one is strictly limited to the group of 18 to 21 years of (offender) age.

Before turning to the results of two-equation models in more detail, some general observations can be reported. As endorsed by estimated single-equation probit models (Table 4 column (1)) and subsequent two-equation models, expected recidivism is higher for those with criminal family background (i.e. parents or sisters have a criminal record), drug or alcohol addiction and for inmates with poor social capital. Recidivism seems to be less likely when a job contact or more years of schooling lead to more optimistic labor market perspectives. These results confirm previous probit results based on all survey inmates $(1,568$ observations) presented in Entorf (2009). The only exception is that social capital was not significant in the full sample whereas it is in the subsample. The strong and highly significant effect throughout all specifications for the young cohort shows that lack of social capital is particularly hazardous for juvenile and adolescent individuals.

Some variables were found insignificant for expected recidivism in column (1) (Table 4) as well as in more complex two-equation models such that they were disregarded in further models of Table 4. These are no church (indicates whether the minor is a member of a protestant, catholic, islamic, etc. church or not), male and age at offense. The insignificance of gender (found throughout all models) is somewhat surprising as results based on the full sample (Entorf 2009) suggest markedly more optimistic future perspectives for females. There might be two explanations for the less optimistic prospects of the young female prison cohort under consideration. The first one is that adolescent females in prisons represent an adverse selection, even regarding the universe of all females and young males in prison, possibly because judges apply the ultima ratio of unconditional imprisonment for young females in a more conservative way than they do for young males or more mature females. The second explanation is that there is convergence of female and male behavior or attitudes such that assessments made by young female cohorts cannot be distinguished any more from those made by their male counterparts. 
Table 4: Econometric Estimation of Two-equation Models

\begin{tabular}{|c|c|c|c|c|c|c|}
\hline & \multicolumn{6}{|c|}{ Expected Recidivism } \\
\hline & \multirow[b]{2}{*}{$\begin{array}{c}(1) \\
\text { Single } \\
\text { Probit } \\
15<x \leq 22\end{array}$} & \multicolumn{5}{|c|}{ Part I of two-equation models } \\
\hline & & $\begin{array}{c}(2) \\
\text { Bivariate } \\
\text { Probit } \\
15<x \leq 22\end{array}$ & $\begin{array}{c}(3) \\
\text { Bivariate } \\
\text { Probit } \\
15<x \leq 22 \\
\end{array}$ & $\begin{array}{c}(4) \\
\text { Bivariate } \\
\text { Probit } \\
18<x \leq 21\end{array}$ & $\begin{array}{c}(5) \\
\text { Treatment } \\
\text { Regression } \\
15<x \leq 22\end{array}$ & $\begin{array}{c}(6) \\
\text { Treatment } \\
\text { Regression } \\
18<x \leq 21\end{array}$ \\
\hline$D(x \geq 18)\left(\rho_{1}\right)$ & $\begin{array}{c}0.650 \\
(0.378)\end{array}$ & $\begin{array}{l}0.414^{* * *} \\
(0.150)\end{array}$ & $\begin{array}{l}0.384^{* *} \\
(0.145)\end{array}$ & - & $\begin{array}{l}0.121^{* *} \\
(0.052)\end{array}$ & - \\
\hline$T(=$ adult $)\left(\rho_{2}\right)$ & $\begin{array}{l}-0.576 \\
(0.644)\end{array}$ & $\begin{array}{l}-1.573^{* *} \\
(0.731)\end{array}$ & $\begin{array}{l}-1.487^{* *} \\
(0.661)\end{array}$ & $\begin{array}{l}-1.604^{* *} \\
(0.612)\end{array}$ & $\begin{array}{l}-0.459^{* *} \\
(0.207)\end{array}$ & $\begin{array}{l}-0.530^{*} \\
(0.253)\end{array}$ \\
\hline $\begin{array}{l}\text { Drug or alcohol } \\
\text { addiction }\end{array}$ & $\begin{array}{l}0.477^{* *} \\
(0.199)\end{array}$ & $\begin{array}{l}0.371^{*} \\
(0.197)\end{array}$ & $\begin{array}{l}0.410^{*} \\
(0.207)\end{array}$ & $\begin{array}{l}0.617^{*} \\
(0.309)\end{array}$ & $\begin{array}{l}0.144^{*} \\
(0.071)\end{array}$ & $\begin{array}{l}0.207^{*} \\
(0.113)\end{array}$ \\
\hline $\begin{array}{l}\text { Criminal family } \\
\text { background }\end{array}$ & $\begin{array}{l}0.495^{* *} \\
(0.188)\end{array}$ & $\begin{array}{l}0.465^{* *} \\
(0.172)\end{array}$ & $\begin{array}{l}0.422^{* *} \\
(0.191)\end{array}$ & $\begin{array}{l}0.578^{* *} \\
(0.272)\end{array}$ & $\begin{array}{l}0.146^{* *} \\
(0.059)\end{array}$ & $\begin{array}{c}0.168 \\
(0.105) \\
\end{array}$ \\
\hline Job contact & $\begin{array}{l}-0.341^{*} \\
(0.174)\end{array}$ & $\begin{array}{c}-0.460^{* * *} \\
(0.133)\end{array}$ & $\begin{array}{l}-0.386^{* * *} \\
(0.127)\end{array}$ & $\begin{array}{l}-0.643 \\
(0.428)\end{array}$ & $\begin{array}{l}-0.108^{* * *} \\
(0.033)\end{array}$ & $\begin{array}{l}-0.146 \\
(0.106)\end{array}$ \\
\hline $\begin{array}{l}\text { Poor social } \\
\text { capital }\end{array}$ & $\begin{array}{l}0.554^{* * * *} \\
(0.166)\end{array}$ & $\begin{array}{l}0.635^{* * *} \\
(0.175)\end{array}$ & $\begin{array}{l}0.566^{* * *} \\
(0.176)\end{array}$ & $\begin{array}{l}0.802^{* * * *} \\
(0.267)\end{array}$ & $\begin{array}{l}0.166^{* * *} \\
(0.054)\end{array}$ & $\begin{array}{l}0.197^{* * * *} \\
(0.057)\end{array}$ \\
\hline No church & $\begin{array}{c}0.110 \\
(0.147) \\
\end{array}$ & $\begin{array}{c}0.101 \\
(0.132) \\
\end{array}$ & - & - & - & - \\
\hline Male & $\begin{array}{l}-0.058 \\
(0.398)\end{array}$ & - & - & - & - & - \\
\hline Schooling & $\begin{array}{l}-0.102^{*} \\
(0.054)\end{array}$ & $\begin{array}{l}-0.089^{*} \\
(0.051)\end{array}$ & $\begin{array}{l}-0.089^{*} \\
(0.048)\end{array}$ & $\begin{array}{l}-0.156^{*} \\
(0.078)\end{array}$ & - & - \\
\hline Age $<18$ & $\begin{array}{l}-0.600 \\
(0.717) \\
\end{array}$ & $\begin{array}{l}-0.471 \\
(0.622) \\
\end{array}$ & $\begin{array}{l}-0.453 \\
(0.606) \\
\end{array}$ & - & $\begin{array}{l}-0.102 \\
(0.185) \\
\end{array}$ & - \\
\hline $18 \leq$ age $<21$ & $\begin{array}{l}-0.837 \\
(0.651)\end{array}$ & $\begin{array}{l}-0.943 \\
(0.680)\end{array}$ & $\begin{array}{l}-0.905 \\
(0.663)\end{array}$ & $\begin{array}{l}-1.163^{*} \\
(0.661)\end{array}$ & $\begin{array}{l}-0.265 \\
(0.210)\end{array}$ & $\begin{array}{l}-0.361 \\
(0.258)\end{array}$ \\
\hline $21 \leq$ age $<22$ & $\begin{array}{l}-0.874 \\
(0.516) \\
\end{array}$ & $\begin{array}{l}-0.944^{*} \\
(0.472)\end{array}$ & $\begin{array}{l}-0.991^{*} \\
(0.483)\end{array}$ & $\begin{array}{l}-0.935^{*} \\
(0.497)\end{array}$ & $\begin{array}{l}-0.311^{*} \\
(0.164)\end{array}$ & $\begin{array}{l}-0.373^{*} \\
(0.208)\end{array}$ \\
\hline $\begin{array}{l}\text { Age at offense } \\
(' x \text { ') }\end{array}$ & $\begin{array}{l}-0.219 \\
(0.183) \\
\end{array}$ & - & - & - & - & - \\
\hline $\begin{array}{l}r \\
{[\mathrm{P}(\mathrm{LR} \text { of } \mathrm{r}=0)]}\end{array}$ & - & $\begin{array}{l}0.764^{* *} \\
{[0.023]}\end{array}$ & $\begin{array}{l}0.698^{* *} \\
{[0.032]}\end{array}$ & $\begin{array}{l}0.744^{*} \\
{[0.054]}\end{array}$ & $\begin{array}{l}0.488^{* *} \\
{[0.030]}\end{array}$ & $\begin{array}{l}0.532^{* *} \\
{[0.046]}\end{array}$ \\
\hline$r \sigma_{\varepsilon}$ & - & - & - & - & $\begin{array}{l}0.211^{* *} \\
(0.071)\end{array}$ & $\begin{array}{l}0.236^{*} \\
(0.096) \\
\end{array}$ \\
\hline P(LR-Test) & 0.035 & 0.000 & 0.000 & 0.000 & 0.004 & 0.009 \\
\hline Nobs. & 159 & 159 & 159 & 78 & 159 & 78 \\
\hline
\end{tabular}


Table 4: (Continued)

\begin{tabular}{|c|c|c|c|c|c|c|c|}
\hline & \multicolumn{7}{|c|}{ Conviction under Adult Criminal Law } \\
\hline & \multirow{3}{*}{$\begin{array}{c}(1 ’) \\
\text { Single } \\
\text { Probit }\end{array}$} & \multicolumn{6}{|c|}{ Part II of two-equation models } \\
\hline & & \multirow{2}{*}{$\begin{array}{c}(2) \\
\text { Bivariate } \\
\text { Probit }\end{array}$} & \multirow{2}{*}{$\begin{array}{c}(3) \\
\text { Bivariate } \\
\text { Probit }\end{array}$} & \multirow{2}{*}{$\begin{array}{c}\text { (4) } \\
\text { Bivariate } \\
\text { Probit }\end{array}$} & \multirow{2}{*}{$\begin{array}{c}\text { (5) } \\
\text { Treatment } \\
\text { Regression }\end{array}$} & \multicolumn{2}{|c|}{ (6) } \\
\hline & & & & & & $\begin{array}{c}\text { Treatment } \\
\text { Regression }\end{array}$ & $\begin{array}{l}\text { Marginal } \\
\text { effects (on } \\
\text { recidivism) }\end{array}$ \\
\hline $\begin{array}{l}\text { Criminal } \\
\text { family } \\
\text { background }\end{array}$ & $\begin{array}{l}0.585^{*} \\
(0.308)\end{array}$ & $\begin{array}{c}0.330 \\
(0.263)\end{array}$ & - & $\begin{array}{l}0.596^{*} \\
(0.283)\end{array}$ & - & - & - \\
\hline $\begin{array}{l}\text { Poor social } \\
\text { capital }\end{array}$ & $\begin{array}{c}0.589 \\
(0.383)\end{array}$ & $\begin{array}{c}0.603 \\
(0.385)\end{array}$ & - & $\begin{array}{c}0.641^{*} \\
(0.349)\end{array}$ & - & - & - \\
\hline No church & $\begin{array}{r}0.428 \\
(0.454) \\
\end{array}$ & $\begin{array}{c}0.374 \\
(0.448) \\
\end{array}$ & - & - & - & - & - \\
\hline Schooling & - & $\begin{array}{c}0.056 \\
(0.055) \\
\end{array}$ & - & - & - & - & - \\
\hline Abitur & $\begin{array}{l}1.584^{* *} \\
(0.583)\end{array}$ & - & $\begin{array}{l}1.398^{* *} \\
(0.619)\end{array}$ & $\begin{array}{l}1.405^{* *} \\
(0.522)\end{array}$ & $\begin{array}{l}1.433^{* *} \\
(0.623)\end{array}$ & $\begin{array}{l}1.250^{*} \\
(0.716)\end{array}$ & $\begin{array}{c}-0.207^{* * *} \\
(0.072)\end{array}$ \\
\hline $\begin{array}{l}\text { Age at offense } \\
(\text { ' } x \text { ') }\end{array}$ & $\begin{array}{l}1.081^{* * *} \\
(0.268)\end{array}$ & $\begin{array}{l}1.439^{* * *} \\
(0.246)\end{array}$ & $\begin{array}{l}1.419^{* * * *} \\
(0.250)\end{array}$ & $\begin{array}{l}1.170^{* * *} \\
(0.252)\end{array}$ & $\begin{array}{l}1.414^{* * *} \\
(0.237)\end{array}$ & $\begin{array}{l}1.144^{* * * *} \\
(0.246)\end{array}$ & $\begin{array}{c}-0.213^{* * *} \\
(0.082)\end{array}$ \\
\hline $\begin{array}{l}\text { Short sentence } \\
\text { (<2 years) }\end{array}$ & $\begin{array}{c}0.577 \\
(0.438)\end{array}$ & $\begin{array}{c}0.198 \\
(0.526)\end{array}$ & - & - & - & - & - \\
\hline Assault & $\begin{array}{c}0.040 \\
(0.392) \\
\end{array}$ & - & - & - & - & - & - \\
\hline Sexual offense & $\begin{array}{c}0.073 \\
(0.909) \\
\end{array}$ & - & - & - & - & - & - \\
\hline Theft & $\begin{array}{c}-0.342 \\
(0.574)\end{array}$ & $\begin{array}{l}-0.750^{*} \\
(0.431)\end{array}$ & $\begin{array}{c}-0.487 \\
(0.355)\end{array}$ & $\begin{array}{c}-0.453 \\
(0.510)\end{array}$ & $\begin{array}{l}-0.461 \\
(0.384)\end{array}$ & $\begin{array}{c}-0.404 \\
(0.500)\end{array}$ & $\begin{array}{c}0.076 \\
(0.106)\end{array}$ \\
\hline Robbery & $\begin{array}{l}-0.868 \\
(0.533) \\
\end{array}$ & $\begin{array}{l}-0.957^{* *} \\
(0.348)\end{array}$ & $\begin{array}{l}-0.753^{* *} \\
(0.314)\end{array}$ & $\begin{array}{l}-0.867^{* *} \\
(0.367)\end{array}$ & $\begin{array}{l}-0.723^{* *} \\
(0.319)\end{array}$ & $\begin{array}{l}-0.746^{*} \\
(0.361)\end{array}$ & $\begin{array}{l}0.142^{* *} \\
(0.064)\end{array}$ \\
\hline Illicit drug use & $\begin{array}{l}-0.812 \\
(0.641)\end{array}$ & $\begin{array}{l}-0.621 \\
(0.586)\end{array}$ & - & - & - & - & - \\
\hline P(LR-Test) & 0.000 & & & quation 0 & pected reci & vism) & \\
\hline Nobs. & 78 & & & & & & \\
\hline
\end{tabular}

Notes: Joint ML estimates of two-equation models (1) and (2). Part II represents eq. (2). Clustered standard errors are shown in parentheses. $\mathrm{P}(\mathrm{LR}-\mathrm{Test})$ indicates the p-value of the likelihood-ratio test of the hypothesis $r=0$. Marginal Effects of binary variables $w$ are calculated as $E(E R \mid T=1, w=1, x, z)-E(E R \mid T=1, w=0, x, z)$; corresponding standard errors are obtained using the delta method. Data: See Tables 1 and A3.

Age at offense is expected to be insignificant because this variable is not directly related to expected recidivism when age of inmates (at the time of the interview) is already controlled for. As descriptive statistics revealed some nonlinear pattern of the influence of age (see also Table 2, Table 3), it is captured using dummies for age intervals. Inmates included in the regression were between 16 and 29 years old when they were interviewed (see Table 1). In Table 4, the (omitted) reference group is 22 years of age or older. There seem to be agedependent moods of inmates which can be characterized as increasingly optimistic until the age of 21 and more pessimistic when getting older than 21 years of age. In order to exclude potential age-dependent nuisance, age dummies are retained throughout all specifications despite their lack of strong statistical significance. 
The idea behind the assignment of explanatory variables to the selection and the treatment equations is to discriminate between the individual personal situation at the time of committing the offense (reconstructing the court's information), and the situation prevailing at the time of the interview. Among the relevant data leading to informed decisions of judges, the type of crime, the degree of maturity and the social situation of defendants should play a role. Turning to estimated equations analyzing the probability of being treated under adult criminal law (Table 4, panel II), results are strongly in line with Figure 1 and confirm the crucial role of age at the moment of committing the crime in question (age at offense). Moreover, a higher degree of education, 'Abitur ${ }^{\text {,11 }}$, increases the probability of being treated as adult. ${ }^{12}$ These results suggest that judges not only consider age but also intellectual maturity as indicators of culpability in the sense of the adult criminal law. Besides these factors, criminal family background and poor social capital seem to have some (weak) relevance for deciding in favor of adult criminal law, possibly because both variables are positively related to unobserved factors such as lack of moral norms, lack of insight in wrongdoing or lack of compliance - all reflecting judges' lack of confidence in future lawabiding behavior. As regards types of crimes, robbery is clearly treated under juvenile crime. Thieves, too, have a higher probability of being convicted as a juvenile, but to a lesser and mostly insignificant extent. Vandalism had to be excluded from the analysis, because, with few exceptions, all cases were treated under juvenile law such that probit achieved perfect predictions of endogenous outcomes. In Table 4, the most severe crimes, murder and sexual offense, are not included in most specifications such that these categories always belong to the reference group (note, however, that inmates can serve for more than one crime). The same holds for drug dealing. Several specifications experimenting with the severity of sanctions show no significant result. Table 4, column (1) presents a model that includes the impact of 'short' prison terms which is found to be positive (but insignificant). As already observed for expected recidivism, religious affiliation has no significant effect on being treated either as adult or as juvenile.

The main focus is on the identification of the causal effect of treatment under 'adult' conditions. The structural parameters of interest capturing the threshold effect between juvenile and non-juvenile law $\left(\rho_{1}\right)$ and the effect of adult criminal law $\left(\rho_{2}\right)$ are both

\footnotetext{
11 'Abitur' is the general qualification for university admission in Germany; it is equivalent to the American high-school diploma, the French 'baccalauréat' and the British 'A level'.

${ }^{12}$ Alternative specifications using years of education lead to the same conclusions, but schooling turned out to be only weakly significant in most specifications such that the degree 'Abitur' was used instead.
} 
insignificant in single equation probit models. However, the single-equation model of recidivism is affected by some 'omitted variable bias' in the sense that the unobserved factor $e$ in the recidivism equation (1) is correlated with unmeasured random determinants captured by $\varepsilon$ in the assignment equation (2). As described in detail in the previous Section, ML estimations of two-equation models presented in column (2) to (6) of Table 4 take this correlation into account. All results, irrespective of estimation method and model specification, indicate a high and positive correlation coefficient $r$. Likelihood-ratio tests show significance at the 5\% level (p-values range between 0.023 and 0.054 ). The positive correlation confirms the presumption that adverse but unobserved common factors such as obvious criminal energy and persistence of unreasonable and unteachable attitudes which lead judges to rule under criminal law cause higher expected recidivism rates.

All two-equation models indicate that the parameter $\rho_{2}$ on application of general criminal law is negative and significant at the $5 \%$ level (see models (2) to (5) of Table 4 ) or at the $10 \%$ level in model (6). These estimates indicate that application of criminal law instead of juvenile law decreases expected recidivism. This result is in line with the hypothesis that treatment under the stricter adult law entails some deterrent effect such that inmates intend to avoid future imprisonment under adult conditions. The alternative explanation is that prisoner rehabilitation and corrective measures are more effective under adult law than under juvenile law. However, the latter view seems to be rather unlikely given the fact that costs per juvenile prisoner exceed those of adult prisoners by about 40 to $50 \%$ which is mainly due to a much higher ratio of personnel per inmate. ${ }^{13}$

The positive estimate of $\rho_{1}$, i.e. the parameter which represents the overall shift from 'pure' juvenile law to a discretionary regime of juvenile and adult law, reveals a smaller but significant upward shift of expected recidivism after turning $18 .^{14}$ Thus, those being older than 18 years of age seem to be less deterred by the mixed regime than those below the threshold of 18 years of age who are strictly treated as juveniles. Again, two interpretations are in order. The first one is that the threat of a weighted risk of juvenile law and adult law increases the inclination to commit future crimes, possibly because inmates know that their personal risk of being affected by adult law is relatively low and because juvenile custody is

\footnotetext{
${ }^{13}$ A survey among the management of German prisons (Entorf et al. 2008, p.144) revealed that the average number of employees per 100 adult inmates amounted to 50 people, whereas the manpower invested for supervision and rehabilitation of 100 juvenile inmates was 71 persons.

${ }^{14}$ Of course, this effect has to be interpreted as the average effect of all ages exceeding 18, i.e. it is different from the local effect one would get from a RD design.
} 
considered not as bad by (criminally experienced) young adults older than 18 years than by 'true' juveniles of, say, 16 or 17 years of age. The second interpretation is that rehabilitation measures are less effective for adolescent offenders.

Looking at bivariate probit results in more detail (Table 4, columns (2) to (4)), we observe that estimates do not change much when we reduce the age-at-offence window from $(15,22]$ to $\left[18,21\right.$ ) (such that $\rho_{1}$ cannot be identified). In the recidivism equation, only job contact loses significance, whereas criminal family background and poor social capital even gain significance in the assignment equation.

Table 4, columns (5) and (6), show estimates for the treatment approach. Specifications differ somewhat from the bivariate probit because inclusion of the inverse Mills ratio in the equation of interest requires some stricter consideration of the exclusion restriction. Hence only age at offence (as general indicator of maturity), 'Abitur' (representing intellectual maturity) and type of offence are used as exogenous factors which are supposed to be of crucial importance for selecting adolescents into either juvenile or adult law, whereas the significance of all remaining variables is tested within the treatment equation. Signs and significance levels of the larger sample do not differ from the ones of bivariate probit (compare columns (5) to (3)), whereas for the smaller sample estimates of the treatment regression are somewhat less significant than those of bivariate probit (see columns (4) and (6)). The high significance of the correlation coefficient $r$ is confirmed. Moreover, $r \sigma_{\varepsilon}$ is positive and significant (although only at the $10 \%$ level in the smaller sample) such that omitting the inverse Mills ratio from the treatment equation would lead to an omitted variable bias.

The last column in the assignment equation shows marginal effects of exogenous factors on expected recidivism (note that the treatment regression is based on the linear probability models such that estimated parameters are identical to marginal effects). These marginal effects are calculated under the restriction that the selection decision is $T=1$, i.e., e.g., for the dichotomous variable Abitur it reads $E(E R \mid T=1, A b i=1, x, z)-E(E R \mid T=1, A b i=0, x, z)$. Marginal effects have opposite signs. This is quite reasonable as can be seen from age at offense or Abitur: Higher maturity increases the probability of being treated as adult which, however, implies that after being selected to such 'adult' conditions adolescents show lower recidivism rates. 


\section{Summary and Conclusions}

This paper addresses the issue of appropriate treatment of young adult offenders. In particular, it is an open question whether they should be treated under juvenile law (with strong emphasis on educational and correctional measures), or under application of the more severe adult criminal law. However, when comparing recidivism rates of both groups, most of the existing surveys studies introduce selection biases that prevent a true comparison of individuals with and without the 'adult' treatment. A major problem is that many studies do not control for pre-existing conditions that may then affect the outcomes.

This paper contributes to the literature on specific deterrence in several ways: First, the study based on the German legal system (which is similar to the one in several other European countries) provides some external evidence to the prevailing literature which is based on the U.S. paradigm, where the line of adulthood is at some younger ages. Second, unlike the situation in the U.S. and in most other countries, turning a critical age cutoff (which is 18 in Germany) does not automatically imply application of the 'adult' law. Instead there is a smooth transition to a fuzzy design of either adult or juvenile legislation. The selection is subject to discretionary court decisions, which depend on the severity of the crime and the personal development of the defendant. This particular situation requires an innovative research design. Application of (fuzzy) regression discontinuity seems to be straightforward. However, the cutoff is hardly noticeable at the age of 18 which limits the usual advantages of RD. Thus, maximum likelihood estimations of a joint two-equation system (selection and treatment equations) have been performed in order to identify the causal effect of the 'adult' treatment, thereby controlling for the selectivity into 'adult' and 'juvenile' regimes.

Results suggest that inmates of the adolescent age group [18,21) convicted under adult criminal law have a lower propensity for future offending. Alcohol and drug addiction, low social capital, criminal family background and bad labor market perspectives belong to the most important factors driving expected recidivism. Inspecting the court decisions in favor of adult criminal law, robbery is most likely treated under juvenile law and intellectual and moral development of defendants seem to be best proxied by age and educational degree ('Abitur').

Results are in line with the hypothesis that treatment under the stricter adult criminal law has some specific deterrent effect such that inmates intend to avoid future imprisonment under such conditions. Of course, results would also be consistent with the alternative explanation that prisoner rehabilitation and corrective measures prescribed for adolescents are less 
effective under juvenile law. This interpretation, however, would suggest highly inefficient measures of social integration as costs per juvenile inmate exceed those of adult criminals by more than 40\% (Entorf et al. 2008).

There are some limitations of this study which could only be derestricted when large-scale individual panel data sets on recidivism were available in Germany. Unfortunately, there is no publicly available source which collects individual information on recidivism and its background factors of the German prison population. The only official source is Jehle et al. (2003) which provides aggregate statistics of recidivism realized during the short period 1994 to $1998 .^{15}$ Thus, even though the number of observations is rather small and data on recidivism are based on self assessment, the present study offers a rare evaluation of factors leading judges to convict defendants under adult criminal law (instead of juvenile law), thereby allowing for testing the specific deterrence hypothesis for adolescent offenders. It is hoped that the study will encourage more research dealing with the problem of selection and recidivism, particularly in European countries.

\footnotetext{
${ }^{15}$ Recidivism statistics do not provide further information on factors of recidivism. Even information on statedependent recidivism rates is withheld by the German Government for political reasons: see the statement made by the Federal Office of Justice (Bundesamt für Justiz, Bonn) in a newspaper article (see FAZ, July 16 ${ }^{\text {th }}$, 2010).
} 


\section{References}

Aebi, M. (2004), Crime Trends in Western Europe from 1990 to 2000. European Journal on Criminal Policy and Research, 10(2), 163-86.

Angrist, J.D., and J.S. Pischke (2009), Mostly Harmless Econometrics: An Empiricist's Companion, Princeton: Princeton University Press.

Becker, G. (1968), Crime and Punishment: An Economic Approach, Journal of Political Economy, 76(2), 169-217.

Bishop, D.M. (2000), Juvenile offenders in the adult criminal justice system, in: M. Tonry (Ed.), Crime and Justice: A Review of Research, Chicago: University of Chicago Press, 81-167.

Bundestag, Deutscher (2009), Antwort der Bundesregierung, Jugendstrafrecht im 21. Jahrhundert, Drucksache, 16-8146.

Corrado, R., I. Cohen, W. Glackman, and C. Odgers (2003), Serious and violent young offenders' decisions to recidivate: An assessment of five sentencing models, Crime \& Delinquency, 49(2), 179-200.

Dünkel, F. (2005), Juvenile Justive in Germany, University of Greifswald, mimeo, http://www.rsf.uni-greifswald.de/fileadmin/mediapool/lehrstuehle/duenkel/ JuvenileJustice.pdf

Entorf, H. (2009), Crime and the Labour Market: Evidence from a Survey of Inmates, Journal of Economics and Statistics, 229/2+3, 254-269, also available as IZA Discussion Paper No 3976: http://ftp.iza.org/dp3976.pdf.

Entorf, H. and H. Spengler (2008), Is Being Soft on Crime the Solution to Rising Crime Rates? Evidence from Germany, IZA Discussion paper No 3710: http: //ftp.iza.org/dp3710.pdf.

Entorf, H. and P. Winker (2008), Investigating the Drugs-Crime Channel in Economics of Crime Models: Evidence from Panel Data of the German States, International Review of Law and Economics 28(1), 8-22.

Entorf, H., S. Pichler and D. Römer (2010), Being Young and Criminal: The Effects of Juvenile Penal and Adult Penal Law on Recidivism, Goethe University of Frankfurt, mimeo.

Entorf, H., S. Meyer and J. Moebert (2008), Evaluation des Justizvollzugs. Ergebnisse einer bundesweiten Feldstudie, Heidelberg: Springer Verlag.

Fagan, J., A. Kupchik, and A. Liberman (2004), Be Careful What You Wish for: Legal Sanctions and Public Safety among Adolescent Offenders in Juvenile and Criminal Court, Columbia Law School, Public Law Research Paper no. 03-61.

Fagan, J. (2008), Juvenile Crime and Criminal Justice: Resolving Border Disputes, Future of Children, 18(2), 81-118.

FAZ (2010), “Wie teuer müssen Gefängnisse sein?”, by Philip Plickert in Frankfurter Allgemeine Zeitung, 16 July 2010.

Goldstein, P. (1985), The Drugs/Violence Nexus: A Tripartite Conceptual Framework. Journal of Drug Issues 15(4), 493-506.

Greene, W. (2008), Econometric Analysis, $6^{\text {th }}$ ed., Upper Saddle River, N.J.: Prentice Hall. 
Greene, W., and D.A. Henscher (2010), Modeling Ordered Choices. A Primer, Cambridge: Cambridge University Press

Harrison, L. D. (1992), The Drug-Crime Nexus in the USA. Contemporary Drug Problems 19(2), 203-246.

Heckman, J. (1979), Sample Selection Bias as a Specification Error, Econometrica 47, 153161.

Heinz, W. (2004), Die neue Rückfallstatistik: Legalbewährung junger Straftäter, Zeitschrift für Jugendkriminalrecht und Jugendhilfe (ZJJ), 1, 35-48.

Huber, P.J. (1967), The Behavior of Maximum Likelihood under Non-Standard Conditions, in Proceedings of the Fifth Berkely Symposium on Mathematical Statistics and Probability, Berkely, CA: University of California Press, Vol 1, 221-233.

Hjalmarsson, R. (2009), Juvenile Jails: A Path to the Straight and Narrow or to Hardened Criminality? Journal of Law and Economics, 52 (Nov), 779-809.

Imbens, G., and T. Lemieux (2008), Regression discontinuity designs: A guide to practice, Journal of Econometrics, 142(2), 615-635.

Imbens, G. and J. Wooldridge (2009), CEA Lecture Notes, May '09, http://homes.chass.utoronto.ca/ siow/2801/imbens\%20woolridge \%20lectures.pdf

Jehle, J.-M., W. Heinz and P. Sutterer (2003), Legalbewährung nach strafrechtlichen Sanktionen: Eine kommentierte Rückfallstatistik, Bundesministerium der Justiz, Berlin.

Lee, D.S. and J. McCrary (2009), The Deterrence Effect of Prison: Dynamic Theory and Evidence, Working Paper \#550 Industrial Relations Section, Princeton University.

Levitt, S. (1998), Juvenile crime and punishment, Journal of Political Economy, 106(6), 1156-1185.

Lochner L. (2007), Individual perceptions of the criminal justice system, American Economic Review 97(1), 444-460.

Lanza-Kaduce, L., J. Lane, D. Bishop, and C. Frazier (2005), Juvenile offenders and adult felony recidivism: The impact of transfer, Journal of Crime and Justice, 28(1), 59-77.

Maddala, G.S. (1983), Limited Dependent Variables and Qualitative Variables in Econometrics, Cambridge: Cambridge University Press.

Mears, D., C. Hay, M. Gertz, and C. Mancini (2007), Public Opinion and the foundation of the juvenile court, Criminology, 45(1), 223-257.

Moffitt, T. (1993), Adolescence-limited and life-course-persistent antisocial behavior: A developmental taxonomy, Psychological Review, 100, 674-674.

Myers, D.L. (2003), The recidivism of violent youths in juvenile and adult court: A consideration of selection bias, Youth Violence and Juvenile Justice, 1(1), 79-101.

Oberwittler, D., and S. Hoefer (2005), Crime and Justice in Germany: An Analysis of Recent Trends and Research, European Journal of Criminology, 2(4), 465-508.

Podkopacz, M., and B. Feld (1995), End of the Line: An Empirical Study of Judicial Waiver, Journal of Criminal Law and Criminology, 86(2), 449-492.

Redding, R. (2005): Adult Punishment for Juvenile Offenders: Does it Reduce Crime?, in N. Dowd, D. Singer, and R. Wilson (Eds.), Handbook of children, culture, and violence, chap. 19. 
Rosch, J., J.W. Owen and L.J. Berlin (2007), Policy Options and considerations for further deliberation, in: Berlin, L.J., J.W. Owen and G. Seaford (Eds.), Juvenile or adult? Adolescent offenders and the line between the juvenile and criminal justices systems. Briefing report prepared for the North Carolina Family Impact Seminar, Durham, NC: Center for Child and Family Polica, Duke University.

Thornberry, T., D. Huizinga, and R. Loeber (2004), The causes and correlates studies: Findings and policy implications, Juvenile Justice, 9(1), 3-19.

Van der Klaauw, W. (2008), Regression Discontinuity Analysis: A Survey of Recent Developments in Economics, Labour, 22(2), 219-245.

Winner, L., L. Lanza-Kaduce, D. M. Bishop and C.E. Frazier, The Transfer of Juveniles to Criminal Court: Reexamining Recidivism Over the Long Term, Crime and Delinquency 43 (1997), 548-63.

White, H. (1982), Maximum Likelihood Estimation of Misspecified Models, Econometrica 50, 1-25. 


\section{APPENDIX}

Table A1: Descriptive statistics: Total sample

\begin{tabular}{|l|l|l|l|l|l|}
\hline Variable & Nobs & Mean & Std. Dev. & Min & Max \\
\hline recidivism (expectation) & 859 & .2188591 & .4137138 & 0 & 1 \\
\hline age at offense & 837 & 31.75876 & 10.85896 & 15.3 & 65.5 \\
\hline age & 859 & 35.13853 & 11.61426 & 16 & 68 \\
\hline male & 859 & .8824214 & .3222961 & 0 & 1 \\
\hline married & 859 & .1734575 & .3788629 & 0 & 1 \\
\hline poor social capital & 859 & .5552969 & .4972224 & 0 & 1 \\
\hline no church & 859 & .2735739 & .4460525 & 0 & 1 \\
\hline criminal family background & 859 & .1699651 & .3758209 & 0 & 1 \\
\hline village & 859 & .2188591 & .4137138 & 0 & 1 \\
\hline addiction (alcohol or drugs) & 859 & .2805588 & .449534 & 0 & 1 \\
\hline good job market prospect & 859 & .2060536 & .404705 & 0 & 1 \\
\hline schooling & 847 & 10.34475 & 2.170845 & 2 & 24 \\
\hline length of prison sentence & 838 & 4.449165 & 3.639345 & .11 & 19 \\
\hline adult & 859 & .8719441 & .3343467 & 0 & 1 \\
\hline murder & 859 & .112922 & .3166818 & 0 & 1 \\
\hline sexual offence & 859 & .1233993 & .3290866 & 0 & 1 \\
\hline assault & 859 & .1897555 & .392336 & 0 & 1 \\
\hline robbery & 859 & .1559953 & .3630623 & 0 & 1 \\
\hline theft & 859 & .233993 & .4236144 & 0 & 1 \\
\hline fraud & 859 & .2153667 & .411316 & 0 & 1 \\
\hline illicit drugs: consumption & 859 & .0698487 & .2550403 & 0 & 1 \\
\hline illicit drugs: dealing & 859 & .1408615 & .3480813 & 0 & 1 \\
\hline vandalism & 859 & .0232829 & .1508884 & 0 & 1 \\
\hline
\end{tabular}

Note: descriptive statistics under the restriction that variables show valid observations on 'recidivism'; Source:

German Inmate Survey (Entorf et al, 2008) 
Table A2: Descriptive statistics, age at offence $=(15,18)$, juvenile penal law

\begin{tabular}{|c|c|c|c|c|c|}
\hline Variable & Nobs & Mean & Std. Dev. & Min & Max \\
\hline recidivism (expectation) & 55 & 0.2909091 & 0.4583678 & 0 & 1 \\
\hline age at offense & 55 & 16.85832 & 0.8070685 & 15.3 & 17.9 \\
\hline age & 55 & 18.85455 & 1.393346 & 16 & 23 \\
\hline male & 55 & 1 & 0 & 1 & 1 \\
\hline married & 55 & 0.0181818 & 0.13484 & 0 & 1 \\
\hline poor social capital & 55 & 0.4727273 & 0.5038572 & 0 & 1 \\
\hline no church & 55 & 0.3454545 & 0.479899 & 0 & 1 \\
\hline criminal family background & 55 & 0.2181818 & 0.4168182 & 0 & 1 \\
\hline village & 55 & 0.1272727 & 0.33635 & 0 & 1 \\
\hline addiction (alcohol or drugs) & 55 & 0.2727273 & 0.4494666 & 0 & 1 \\
\hline job contact & 55 & 0.2181818 & 0.4168182 & 0 & 1 \\
\hline schooling & 55 & 9.290909 & 1.565516 & 4 & 12 \\
\hline length (of prison sentence) & 55 & 2.907576 & 2.141933 & 0.5 & 9.5 \\
\hline (application of) criminal law & 55 & 0 & 0 & 0 & 0 \\
\hline murder & 55 & 0.1272727 & 0.33635 & 0 & 1 \\
\hline sexual offence & 55 & 0.0363636 & 0.1889186 & 0 & 1 \\
\hline assault & 55 & 0.4909091 & 0.504525 & 0 & 1 \\
\hline robbery & 55 & 0.4363636 & 0.5005048 & 0 & 1 \\
\hline theft & 55 & 0.5636364 & 0.5005048 & 0 & 1 \\
\hline fraud & 55 & 0.1090909 & 0.3146266 & 0 & 1 \\
\hline illicit drugs: consumption & 55 & 0.0363636 & 0.1889186 & 0 & 1 \\
\hline illicit drugs: dealing & 55 & 0.1272727 & 0.33635 & 0 & 1 \\
\hline vandalism & 55 & 0.1636364 & 0.373355 & 0 & 1 \\
\hline
\end{tabular}

Note: descriptive statistics under the restriction that variables show valid observations on 'recidivism'; Source: German Inmate Survey (Entorf et al, 2008) 
Table A3: Descriptive statistics, age at offence $=[18,21)$, young adults (juvenile or adult law)

\begin{tabular}{|l|r|r|r|r|r|}
\hline Variable & Nobs & Mean & \multicolumn{1}{l|}{ Std. Dev. } & Min & Max \\
\hline recidivism (expectation) & 78 & 0.3205128 & 0.4696943 & 0 & 1 \\
\hline age at offense & 78 & 19.64153 & 0.9005078 & 18 & 20.9 \\
\hline age & 78 & 21.79487 & 2.188274 & 19 & 29 \\
\hline male & 78 & 0.9358974 & 0.2465209 & 0 & 1 \\
\hline married & 78 & 0.1025641 & 0.3053524 & 0 & 1 \\
\hline poor social capital & 78 & 0.4487179 & 0.5005824 & 0 & 1 \\
\hline no church & 78 & 0.3717949 & 0.4864121 & 0 & 1 \\
\hline criminal family background & 78 & 0.2692308 & 0.4464311 & 0 & 1 \\
\hline village & 78 & 0.1538462 & 0.3631365 & 0 & 1 \\
\hline addiction (alcohol or drugs) & 78 & 0.2948718 & 0.4589365 & 0 & 1 \\
\hline good job market prospect & 78 & 0.1923077 & 0.3966644 & 0 & 1 \\
\hline schooling & 78 & 10.03846 & 2.263157 & 3 & 17 \\
\hline length of prison sentence & 76 & 3.192982 & 2.758563 & 0.3 & 15 \\
\hline application of criminal law & 78 & 0.2820513 & 0.4529108 & 0 & 1 \\
\hline murder & 78 & 0.1282051 & 0.336482 & 0 & 1 \\
\hline sexual offence & 78 & 0.0384615 & 0.1935524 & 0 & 1 \\
\hline assault & 78 & 0.3974359 & 0.492535 & 0 & 1 \\
\hline robbery & 78 & 0.2948718 & 0.4589365 & 0 & 1 \\
\hline theft & 78 & 0.3333333 & 0.4744557 & 0 & 1 \\
\hline fraud & 78 & 0.2179487 & 0.4155246 & 0 & 1 \\
\hline illicit drugs: consumption & 78 & 0.0897436 & 0.287664 & 0 & 1 \\
\hline illicit drugs: dealing & 78 & 0.1410256 & 0.3503008 & 0 & 1 \\
\hline vandalism & 78 & 0.1282051 & 0.336482 & 0 & 1 \\
\hline
\end{tabular}

Note: descriptive statistics under the restriction that variables show valid observations on 'recidivism'; Source: German Inmate Survey (Entorf et al, 2008) 
Table A4: Descriptive statistics, age at offence $=[21,22]$, adult criminal law

\begin{tabular}{|c|c|c|c|c|c|}
\hline Variable & Nobs & Mean & Std. Dev. & Min & Max \\
\hline recidivism (expectation) & 26 & 0.1923077 & 0.4019185 & 0 & 1 \\
\hline age at offense & 26 & 21.54961 & 0.2781412 & 21 & 22 \\
\hline age & 26 & 24.30769 & 1.783687 & 22 & 29 \\
\hline male & 26 & 0.7692308 & 0.4296689 & 0 & 1 \\
\hline married & 26 & 0.1538462 & 0.3679465 & 0 & 1 \\
\hline poor social capital & 26 & 0.6153846 & 0.4961389 & 0 & 1 \\
\hline no church & 26 & 0.2307692 & 0.4296689 & 0 & 1 \\
\hline criminal family background & 26 & 0.0769231 & 0.2717465 & 0 & 1 \\
\hline village & 26 & 0.3076923 & 0.4706787 & 0 & 1 \\
\hline addiction (alcohol or drugs) & 26 & 0.3076923 & 0.4706787 & 0 & 1 \\
\hline good job market prospect & 26 & 0.1538462 & 0.3679465 & 0 & 1 \\
\hline schooling & 26 & 10.38462 & 2.401282 & 2 & 15 \\
\hline length of prison sentence & 26 & 3.645833 & 3.224715 & 0.2 & 14 \\
\hline application of criminal law & 26 & 1 & 0 & 1 & 1 \\
\hline murder & 26 & 0.0769231 & 0.2717465 & 0 & 1 \\
\hline sexual offence & 26 & 0.1153846 & 0.3258126 & 0 & 1 \\
\hline assault & 26 & 0.1153846 & 0.3258126 & 0 & 1 \\
\hline robbery & 26 & 0.1153846 & 0.3258126 & 0 & 1 \\
\hline theft & 26 & 0.3461538 & 0.4851645 & 0 & 1 \\
\hline fraud & 26 & 0.2307692 & 0.4296689 & 0 & 1 \\
\hline illicit drugs: consumption & 26 & 0.1153846 & 0.3258126 & 0 & 1 \\
\hline illicit drugs: dealing & 26 & 0.1538462 & 0.3679465 & 0 & 1 \\
\hline vandalism & 26 & 0 & 0 & 0 & 0 \\
\hline
\end{tabular}

Note: descriptive statistics under the restriction that variables show valid observations on 'recidivism'; Source:

German Inmate Survey (Entorf et al, 2008) 